Cahiers $d u$ MONDE RUSSE

\section{Cahiers du monde russe}

Russie - Empire russe - Union soviétique et États indépendants

$55 / 1-2 \mid 2014$

Fiscalité, justice et conflit politique en Russie, premier tiers du XVIIle siècle

\title{
Possevino and the death of tsarevich Ivan Ivanovich
}

Possevino et la mort du tsarevič Ivan Ivanovič

\section{Paul Bushkovitch}

\section{(2) OpenEdition \\ 1 Journals}

Electronic version

URL: http://journals.openedition.org/monderusse/7988

DOI: $10.4000 /$ monderusse. 7988

ISSN: $1777-5388$

Publisher

Éditions de l'EHESS

\section{Printed version}

Date of publication: 1 January 2014

Number of pages: 119-134

ISBN: 9782713224409

ISSN: $1252-6576$

Electronic reference

Paul Bushkovitch, «Possevino and the death of tsarevich Ivan Ivanovich », Cahiers du monde russe [Online], 55/1-2 | 2014, Online since 01 January 2017, Connection on 19 April 2019. URL : http:// journals.openedition.org/monderusse/7988; DOI : 10.4000/monderusse.7988

This text was automatically generated on 19 April 2019 


\title{
Possevino and the death of tsarevich Ivan Ivanovich
}

\author{
Possevino et la mort du tsarevič Ivan Ivanovič
}

\author{
Paul Bushkovitch
}

1 Historians of early modern Russia have mined the accounts of foreigners in Russia for nearly two centuries. Mostly commonly they use them to find details not reflected in Russian sources, such as court and church rituals, and for the outsider's view of the country. Much of the latter revolves around understanding the source of various stereotypes of the country that prevailed in Western Europe. All of this literature has contributed to our understanding of Russian history, but many issues remained unresolved. ${ }^{1}$

If we are to use these sources, we must understand not merely general cultural prejudices but the character of the documents themselves. A useful starting point is to avoid putting them all in the same category as "travellers' accounts" or even the more useful "state descriptions." One important category is the published works of diplomats, which include some of the most important and most frequently cited, those of Herberstein, Possevino, Fletcher, and Olearius. The diplomats all had a concrete task and were supposed to report back to their sovereigns what they actually saw and did, not to provide propaganda for this or that cause or stereotype. Of course their published works did some of both, and indeed we can find all the stereotypes that we want in them alongside accurate, or at least well-intentioned, information. For the sixteenth century diplomatic publications we also normally have no unpublished archival sources. That is to say, the dispatches of Herberstein and Fletcher do not seem to exist in the relevant archives so the published books are our only sources for these missions. In the case of Olearius it is not clear to me if anyone has ever looked, perhaps they do exist. ${ }^{2}$ For the missions of Antonio Possevino S.J. in 1581-1582 the manuscripts of the actual final relations to Rome do not seem to have been found and may not survive, but a great deal of correspondence to and from Possevino is extant and has even been published in a variety of collections. ${ }^{3}$ 
3 The presence or absence of unpublished archival material is not merely a matter of antiquarian interest. An examination of published material from embassies to Russia and other European countries at the end of the seventeenth century reveals interesting differences. In the 1690's the Habsburg ambassador to Moscow was one Ignaz von Guarient and his secretary Johann Korb. As the embassy's secretary, Korb presumably wrote or copied Guarient's dispatches. He also published in Latin on return to Vienna a diary of the mission, long exploited as a source for the early years of Peter's reign. A comparison of the unpublished dispatches with the diary reveals some interesting differences. The dispatches were filled with information about the various factions among the Russian boyars and Peter's conflicts with them. All that material was absent from the published diary, an absence that gave a basically false picture of the politics of the Russian court. ${ }^{4}$ This sort of difference is not unique to the later seventeenth century nor to publications of European diplomats in Russia, for it seems to have been a general practice to omit that sort of information in published accounts of any country. Reading Herberstein's bland account of the boyars, one only wonders what he wrote for the eyes of his sovereign and his councilors. Fletcher as well gave no hint of the divisions among the elite which fill the pages of the work of modern historians.

4 Possevino's Moscovia of 1586 is one such published account. Possevino was a Jesuit priest with an agenda for the recatholicization of Eastern Europe, but he was also a diplomat, sent by Pope Gregory XIII to Poland and Russia to help mediate a peace that would free both countries to oppose the might of the Ottoman Empire. It would be useful to analyze the text more fully in the light of Possevino's correspondence, but here we will confine ourselves to one incident, the story of Ivan's murder of his son Ivan Ivanovich in 1581. This story is one of the classics of Russian history, retold by Karamzin and all later historians and most famous from the Repin painting. ${ }^{5}$ The death of the tsarevich became a theme all of its own in modern Russian culture. ${ }^{6}$ Yet the correspondence of Possevino provides a quite different picture from the printed book. In this case it is not the book that omitted what was in the letters but rather the reverse. The letters do not contain the story and indeed contradict it, which appeared only in the published book.

Possevino went to Russia to talk to Ivan the Terrible as the papal emissary in order to further peace negotiations between Russia and Poland. By the summer of 1581 Ivan's attempt to annex Livonia had failed, with the Swedes ensconced in northern Estonia and the king of Poland, Stefan Batory, besieging Pskov from 18 August onwards. Both the Pope and Emperor were unhappy with the continuing conflict, since it made it impossible to recruit either Poland or Russia as allies against the Turks. ${ }^{7}$ The result was two journeys by Possevino to Russia, the first on 5 August- 5 October, 1581, to meet the tsar at Staritsa. Possevino then went to the Polish camp at Pskov, where he found the army low on gunpowder and morale under pelting rain. Batory agreed to discuss peace, and Possevino sent his translator, Andrei Polonskii, back to Ivan. Polonskii met the tsar (and tsarevich Ivan Ivanovich, alive and healthy) in Aleksandrova Sloboda and hurried back with a positive answer. The next months were taken up with the negotiations, crowned with success on 15 January, 1582 at Iam Zapol'skii, in large part due to the Jesuit's efforts. Ivan surrendered Livonia, but Batory evacuated all his conquests in Russia itself. ${ }^{8}$ Possevino then made a second journey to confirm the truce in Moscow itself on 23 January-14 March, 1582.

6 Possevino's account of his journeys, his observations of Russia, his discussion with Ivan and the story of the killing of Ivan Ivanovich appeared in the first chapter of his 
Moscovia, first published in Wilno in 1586 and later reprinted several times. ${ }^{9}$ The story was an episode in the first chapter, which provided a general description of Russia and suggestions on how to negotiate with its rulers. The second chapter was an account of the 1581 mission composed, as the text says, at the time. It too began with general information about Russia and mentioned both of Ivan's sons as alive. Chapters three through four covered the 1582 mission to Moscow and the debates between Possevino and Ivan on religious issues. The final chapter recounted the Russo-Polish negotiations of December 1581-January 1582. The book's chronology was thus rather complicated.

7 Possevino's story in the first chapter was that "There is strong evidence [certiore indicio proditum est] that the Grand Prince of Moscow slew his own son in the fortress called Alexandrova Sloboda." He claims that he heard the story from one of the interpreters, presumably one with whom he worked in February and March, 1582. Both of Possevino's interpreters were Lithuanians, one of whom had been with the tsarevich [apud eum] and in Graham's translation of Possevino's words "looked into the cause of his death and gave me the more probable account of it". The result was the well-known story of Ivan's blow to the wife of the tsarevich and the subsequent quarrel and blow to the son. ${ }^{10}$ Hugh Graham's English conveyed Possevino's caution but literally the story was "put about (note the irresponsible passive voice: by whom?) as more certain information" and "those who had looked into the truth brought this as more true" [qui vertitatem scrutati sunt... hanc veriorem retulere]. Historians have not usually noted the qualifications. ${ }^{11}$ Possevino also stated that he recounted the story because

it would be worth it to know (as it is worthy of memory, and had not a little importance in inclining the prince to hear many things which we discussed with him more mildly than he perhaps might have done)

[(quod ea res memoratu digna sit, nec mediocre habuerit momentum ad Principem flectendum, ut multa, quae cum eo agebamus, mitius, quam fortasse fecisset, audiret) operae pretium fuerit nosse)]. ${ }^{12}$

It is not clear what these "many things" were, but presumably the proposals for peace or conversion to Catholicism.

More serious is the phrase about the translator, which both Graham and L.N. Godovikova translated incorrectly. Graham rendered Possevino's “tum erat apud eum alter ex interpretibus meis, quem ad ipsum allegaveram" as "one of the interpreters assigned to me had been in the young prince's service at the time". Godovikova was more accurate with “ПРИ НЕМ В ЭТО ВРЕМЯ НАХОДИЛСЯ ОДИН ИЗ ОСТАВЛЕННЫХ МНОЮ ПЕРЕВОДЧИКОВ." ${ }^{13} \mathrm{~A}$ fully accurate translation, however, would be "then with him was the other of my interpreters, whom I had sent to the same." All the translators have interpreted "eum" in "apud eum" as referring to Ivan Ivanovich, though it could mean Ivan IV. In either case, Possevino is telling us that he sent one of his interpreters to the Russian court after he, Possevino, had returned to the Polish camp near Pskov. If that is the case, the conclusion drawn by Pierling and subsequent historians that the interpreter must be Vasilii Zamasskii and that he was somehow with the tsarevich must be wrong. ${ }^{14}$ In Possevino's letter of 16 November 1581 to Ivan IV, he told him that his interpreter Andrei Polonskii had returned from the Russian court yesterday and that he was sending Zamasskii to Novgorod with the Russian courier Zakharii Boltin (who had come to the Polish camp with Polonskii) to get letters from the Russian generals. Ivan Ivanovich, however, was already ill on 12 November and died on 19 November. Both father and son were in Aleksandrova Sloboda, and Ivan IV remained there through November. ${ }^{15}$ Zamasskii could not have been anywhere near the event. The only other interpreter 
known to scholars was the same Andrei Polonskii, who had been in Aleksandrova Sloboda in October, arriving on 20 October and departing, it seems, already on the 23 after a decision by Ivan, his son Ivan, and the boyars to ask Possevino to convince King Stefan to make peace. The order to the pristav Leontii Andreev syn Stremoukhov had been to ensure that while he was there, Polonskii would communicate with no one.${ }^{16} \mathrm{He}$ may have left later than 23 October, but he was back with Possevino when the latter wrote the letter on 16 November to Ivan (above) but was ill and died by 13 December, leaving Possevino with only one Russian translator. Possevino's letter of 14/15 December to Jan Zamoyski, Poland's Chancellor, evidently crossed, for the Jesuit did not know that the Chancellor knew of Polonskii's death, and it left him in the same situation: only one Russian translator, presumably Zamasskii. He begged Zamoyski for another translator. ${ }^{17}$

The inescapable conclusion is that neither Polonskii or Zamasskii were at the Russian court at Aleksandrova Sloboda at the time of the death of tsarevich Ivan. That conclusion comes not from the main text of the Moscovia but from the letters appended to it. The 1586 Wilno edition has most of these letters, but the 1587 Antwerp edition (which Graham used) does not have them at all. Turgenev printed these letters in 1842 with the Moscovia, and evidently Pierling used that text. Possevino makes it quite clear in his letters that he had only the two translators, which is also implied by his choice of words; "alter [emphasis added] ex interpretibus meis", since "alter" means "one of two". "One" would have to be "unus" or "aliquis". If the translators missed this point, they were correct to translate "tum" as "at the time". To be sure, "tum", like English "then", is vague, but the context points to the time of the death of the tsarevich. It is difficult to imagine any other meaning. In that case Possevino was lying, since his letters make it clear that neither Zamasskii nor Polonskii were in Aleksandrova Sloboda during the crucial days in November, 1581, and he had only the two translators. What is peculiar about the contradiction between the main text (the second commentary) and the letters is that Possevino published both. If we are to believe the Wilno publisher, he worked with Possevino because of the imperfect texts circulating in manuscript. ${ }^{18}$ The Moscovia did not give a date for the death of the tsarevich, so the reader who did not know it would miss the contradiction, but Pierling and other modern scholars should have seen it. Finally, in Possevino's unpublished (at the time) correspondence with Rome and the Polish authorities he does not mention any incident, illness, or death of the tsarevich until early January when he heard the first rumors circulating the Polish camp (see below). Polonskii must have left Aleksandrova Sloboda when the tsarevich was still alive and well, taking about three weeks (October 23-November15) to join his master. Neither translator was the source of the story, in spite of Possevino's assertion in the Moscovia.

To complicate matters further, earlier on in the "first" (chapter one but written second) commentary Possevino tells us that after the first journey he left "two men" for five months who observed many things: "cum item apud Moscum reliquissem duos homines, qui, dum ab eo aberam, mensium quinque spatio multa observarunt." ${ }^{19}$ These two cannot be the same as the two interpreters, since he claimed that he had sent "the other" of his interpreters to Moscow, not left him there. The "two men" were Father Stefan Drenocki, a Croatian Jesuit, and his Milanese companion Michele Morieno. On the basis of this passage Godovikova believed Drenocki to be the source of the story, but Possevino himself reported in the Moscovia that they were kept in total isolation from the time of Possevino's departure to his return. ${ }^{20}$ Drenocki could not be the source of the story, or if he was, then he too could only report rumors. 
11 There is another text from these missions, republished in 1882 by Paul Pierling, S.J. ${ }^{21}$ This is the "Missio Moscovitica", and first published in the Annuæ Litteræ Societatis Jesu anni MDLXXXII ad patres et fratres ejusdem societatis, Rome, 1584. As Pierling established, the text is actually a composite of the 28 April 1582 letter of Possevino to Claudio Acquaviva, the head of the Jesuit order, and the report on Russia by his companion in 1581, Giovanni Paolo Campana S.J. The only mention of Ivan Ivanovich in this text comes in the description of the 1581 mission. The tsarevich was present at the audience for Possevino, seated like his father but on chair placed on a lower level (25). Ivan Ivanovich participated in other ceremonies of the audience (26-28) and the succeeding banquet (31), as well as the final audience (41). The text continues with a brief account of Possevino's involvement with the truce negotiations, and then an account of the 1582 return to Moscow and Possevino's debates with Ivan on religion. The text records Possevino's arrival in Rome with the Russian ambassadors in September, 1582 (58). The second half of the "Missio" is Campana's notes on Russia. Campana was in Russia before the death of Ivan Ivanovich, and only mentions him indirectly in describing the ritual of the New Year ( $1^{\text {st }}$ September) blessing of the Tsar and his sons by the Metropolitan (70). The text also mentions (59) that a "commentarius" (singular) by Possevino about the customs of the Muscovites "is said to exist" (existare dicitur). This must have been the "first commentary" that was printed as the second. The 1584 version of Possevino and Campana's reports does not even mention the death of the tsarevich, though it was clearly compiled after September, $1582 .^{22}$

These sixteenth century publications are hardly the whole story of Possevino and the death of the tsarevich, for the 1586 account of that death as murder is not found in any of his then unpublished letters to Rome and elsewhere from the moment of the death of Ivan Ivanovich onwards until the Moscovia appeared in print in 1586. Possevino even told the Poles that the stories about Ivan's "barbarism" were not true, as the royal secretary Jan Piotrowski recorded in his diary under 22 November. ${ }^{23}$ Later on Possevino certainly heard the stories of the death of the tsarevich. The stories began to circulate at the Polish army camp at Kiverova Gorka near Pskov at the end of December, 1581. The Polish commander Spytek Jordan wrote to Zamoyski on 26 December that he had "news from informants," that everyone, even peasants, were saying that the son of the Grand Duke had died, that the tsar was very sad and giving alms to monasteries. ${ }^{24}$ Four days later Zamoyski wrote to Possevino briefly that "Here news has come to me that Ivan the first born son of the Grand Duke is dead." ${ }^{25}$ On 2 January 1582 Zamoyski informed King Stefan: "From prisoners and spies at Novgorod I have understood that the eldest son of the Muscovite has died." 26 On January 6, 1582, Possevino wrote to Ptolomeo Galli, cardinal of Como, the Papal Secretary of State, that he had heard a rumor of the death of the tsarevich from Zamoyski, adding that the only remaining son was the one whose qualities he had described in his commentary on Muscovy, which must mean the "second" commentary of the Moscovia. ${ }^{27}$ A brief note from Zamoyski to the Danish prince Magnus on 8 January gave news of a victorious battle at Pskov and told another story with its 
sources: "[we learn] from the mob that 300 Muscovites have fallen, that the son of the Grand Duke died also there, and many were wounded and captured." ${ }^{28}$ (Note that the rumor was that Ivan Ivanovich was fighting before Pskov, which was not the case.) There is nothing in any of this correspondence about a quarrel or murder. A few days later, on 15 January, the Russian and Polish diplomats signed the truce of Iam Zapol'skii, a moment of triumph for Possevino. The first mention of a purported violent death of the tsarevich came in Possevino's letter of 22 January to Galli.

La morte, anzi uccisione del figlio primogenito dal Moscovito, fatta dal padre si conferma et dicesi così esser stata per cagione ch'egli al padre ricordò la morte di molti, et il bene ch'era per seguir della pace. Alla quale perchè il Moscovito mi si mostrò inclinato sempre, non so quanto debbo credere a si fatti romori.

[The death, or rather murder, of the first born son of the Muscovite committed by the father, is confirmed and is said to be for the reason that he reminded his father of the death of many and that it would be good to look for peace. To which the Muscovite, however, always showed himself to me to be inclined, so I do not know how much I should believe rumors thus constructed.] ${ }^{29}$

13 In other words, Possevino was hearing rumors from the Polish authorities. The story of the murder in this letter was not a fact he learned from his interpreters but a rumor, again contradicting the Moscovia version. The story that was circulating said that Ivan had killed his son, but the reason was that the tsarevich wanted peace and Ivan did not. Possevino did not believe the rumors, in part because he (correctly) believed that Ivan wanted peace, so that could not be a cause for a quarrel. The statement that he believed Ivan to always (sempre) incline toward peace also contradicts the statement in the Moscovia that the death of the tsarevich made Ivan listen "more mildly" (mitius) to what Possevino said to him. The rumor differed from the Moscovia version in another crucial respect: the cause of the murder was not a conflict over the wife of the tsarevich but over the issue of peace or war. Possevino, by his own admission, did not, as he later asserted, know as a fact that Ivan killed his son because of the tsar's quarrel with his daughter in law, in reality he heard a rumor (which he did not believe) that the father and son quarreled over the war.

Possevino's attitude at the time also emerges from his letter to Zamoyski written only a week later, 29 January 1582, where he reported simply that "Filius Magni Ducis primogenitus, ut dudum erat rumor, [blank] diem obiit" ("The first born of the Grand Duke, as was for some time the rumor, on [blank] day died". ${ }^{30}$ "Died" (obiit), not "was murdered". Back in Moscow in February, Possevino wrote to Galli mentioning the death of the tsarevich, but nothing about its cause. Perhaps he did not want to be too open at that point, but in his remaining correspondence with Bolognetti and Galli the subject never came up. The only question about Ivan's sons was the capacities of Fyodor and the rumors of the birth of tsarevich Dmitrii in $1582 .{ }^{31}$ His report to Aquaviva, the General of the Jesuit order, from 28 April, 1582, written after he left Russia, also does not mention the death of the tsarevich though he reported on the whole mission to Moscow. ${ }^{32}$

Possevino did discuss the tsarevich, or at least mention him, in his reports written in Venice where he stopped on the way from Moscow to Rome with the Russian ambassador, Iakov Molvianinov. He delivered several reports and proposals to the Venetian Doge and Senate, including a discourse on the need to form a league against the Turks, which had been one of the principal aims of Papal diplomacy. (It was that desire that had incited Rome to mediate a truce between Russia and Poland by sending Possevino to meet Ivan IV.) In his discourse to the Venetians on 12 August, 1582, Possevino ${ }^{33}$ laid out the 
difficulties to such a project, primarily the fact that all the relevant rulers of Europe were either preoccupied with other issues or just not interested. In the case of Ivan IV, the Jesuit adduced his poor health, that he slept poorly, often waking up at night and was "pieno di melancolia doppo la morte del primogenito." ("full of melancholy after the death of his son"). ${ }^{34}$ In the report he said "morte," meaning "death", not "uccisione," meaning "murder". This was a private report to the Venetian authorities, and there was no reason for him not to say that Ivan had killed his son unless he did not believe it. None of the Venetian documents of conversations with Possevino records any version of the rumors of the murder of the tsarevich. By August, 1582, his death was no longer news, but had Possevino believed that Ivan had killed his son, it is hard to believe that he would have considered the fact irrelevant in evaluating the tsar's personality and abilities to conduct affairs of state. Much of Possevino's correspondence and the report in question revolved precisely around the personalities of the monarchs, including Ivan.

Subsequent correspondence throws some light on the composition of the Moscovia. In 1583 Possevino went on another mission to Hungary and Transylvania, after which he returned to Poland..$^{35}$ The first mention of the Moscovia came in his report to Pope Gregory XIII on Livonia dated Bartfa in Hungary (Bardejov, Slovakia), 30 March, 1583. Here he referred to his "second book" on Muscovy, though it is not clear what part of the final text that comprised. In the preceding pages of the Livonia he briefly described the story of the Polish succession from the death of Sigismund August and Ivan's conquests in Livonia during the time Stefan Batory was occupied with the rebellious city of Danzig, and then asserted that "about all this matter he had written enough in his second book on Muscovy" (Qua de tota re satis multa scripsi in secondo de Moscovia libro...) ${ }^{36}$ Godovikova correctly interpreted this "second book" to be the commentary that appeared as the first chapter in the 1586 Moscovia, since the date of the other was clearly from September, $1581 .{ }^{37}$ Thus by March, 1583, there were clearly two commentaries.

Work must have continued on that commentary. In his notes to his edition of the "Missio Moscovitica" Pierling cited a letter from Possevino to Cardinal Galli from Krakow, 11 February 1584, where Possevino explains that he had written a second commentary on Muscovy while he was in Hungary in $1583 .^{38}$ Possevino wrote that he was sending the Cardinal:

un piccolo libro delle cose di Moscovia il quale è il secondo commentario ch'ultimamente ho fatto in Ungheria, conforme ad alcuni avvertimenti che V. S. Illma mi diede, pertinenti alle cose politiche et altre.

[a little book of the affairs of Muscovy which is the second commentary which I made in Hungary in conformity with some information that your lordship gave me pertinent to political and other matters].

In the Moscovia Possevino stated twice that the "second commentary", the second chapter, in that book was composed during the first mission (1581) ${ }^{39}$ Thus what he called the "second commentary" in the 1584 letter to Galli must be what became the "first commentary", the first chapter, in the Moscovia, that is, the part with the story of the death of the heir, and it was composed at least three years after the events. In other words, Possevino wrote up his report using information that came from other sources than his own memory or notes, and it seems that he was more or less commanded to use that information. Possevino had sent earlier on 9 December 1583 to the nuncio Bolognetti a copy of the "second commentary", on Muscovy, again this must have been the same "second commentary" (on 1582) that appeared as the first commentary in the printed edition of 1586. He commented: "Può essere che tali cose qualche volta serviranno come 
potrà comprender." ("It may be that such things will be useful some time, as one may understand"). ${ }^{40}$ What is not clear is why Possevino had to be asked to write the "second commentary" on the 1582 embassy to Moscow, and why he had to use "avvertimenti" from Galli. In the published text he claimed that his sources, besides Drenocki and Morieno (by his own admission, how much help could they have been?), were historical writings, and discussions with ambassadors and the kings of Poland and Sweden, as well as Ivan's own words. Presumably this means his own notes and letters on those discussions. He did not mention any "information" from Galli. From the letter to Bolognetti, it seems that the new text was to be kept for some later purpose. We have no idea what that was. It would be easy to speculate on the basis of our knowledge of Papal and Polish politics and relations with Russia, but that would be nothing more, just speculation.

We do not know the exact context of the publication of the Moscovia. In February, 1585, Galli ordered Possevino to leave the Polish court and to retire to the Jesuit college in Braunsberg, in Royal (Polish) Prussia. According to Pierling the reason was that Possevino had become too supportive of Stefan Batory's plans for the conquest of Russia, which Pope Gregory XIII found incompatible with his own plans for a Turkish crusade and his relations with Emperor Rudolf. ${ }^{41}$ Possevino went to Braunsberg, though he violated Roman orders by travelling to Dorpat and elsewhere in Livonia to advance the Catholic cause. King Stefan's plans for conquest only grew more extravagant, but the new (May, 1585) Pope Sixtus $V$ was even more skeptical than his predecessor. The King of Poland maintained that the best way to defeat the Turks was by the conquest of Moscow. That was the problem: neither Pope was against the conquest of Russia for the Catholic cause, but it was expensive (the Papacy would have to pay for the war, given the opposition in the Polish diet) and it might not work. Possevino wrote to Rome early in 1586 again as advocate for the king's plans, and in the summer the Roman authorities called him back. He arrived in Rome in September, 1586. There he managed to convince Sixtus that Batory's plan was workable, and in December Possevino set off for Warsaw by way of Venice. Unfortunately, Stefan Batory died on 12 December, 1586, rendering all the schemes irrelevant. ${ }^{42}$ The only reference to the Moscovia in this period seems to be Pierling's comment that Possevino discussed it with Annibale di Capua, the new nuncio to Poland on the way from Rome to Venice in December, $1586 .{ }^{43}$ If this was the printed book and not a manuscript, then it must have been printed in the first part of the year 1586, before Possevino went to Rome. That he brought it with him suggests that part of its purpose to convince the Roman curia of the viability of Stefan Batory's plans. The book did elicit some discussion in Poland, since Zamoyski was unhappy that Possevino had published royal correspondence in the letters appended to the Wilno edition. Possevino defended himself early in 1588 from Padua by noting that he had followed the advice of Heidenstein and omitted some details that might offend the Russians "while peace is being dealt with" (dum pax curaretur) and suppressed Batory's "long letter" to Ivan IV, keeping it for quieter times. ${ }^{44}$

Possevino touched on Russian affairs only once more, in a letter of 1587 prompted by the Polish discussions of succession after Batory's death. Here he did mention Ivan Ivanovich. He said that he spoke with the tsarevich, though not with his younger brother, and he did not even allude to the story of his death found in the Moscovia. He wrote that he published his Moscovia "urgentibus cordatissimis viris" (as most prudent men were urging). ${ }^{45}$ What that meant is anyone's guess. Rome recalled Possevino in April, 1587, and 
he went to Padua, spending the rest of his life teaching and writing, primarily the Bibliotheca selecta, his vast compilation and bibliography of theology. other sources do exist. They are not in any way definitive. Reinhold Heidenstein (Stefan Batory's secretary) tells the story that Ivan killed his son, though not in the same version as Possevino. Heidenstein presented two stories, one of which which he asserted came from two noble Muscovite prisoners ("duos nobiles Moscos"). Their story was that the blow came from dispute arising from mutual bragging, the other story ("some say" "quidam dicerent") that the quarrel arose from the son's desire to take his own army to Pskov. Ivan, in the story, then struck his son, and either from the blow or from the force of pain of the soul, the son fell into an epilectic fit and a fever and then died. ${ }^{46}$ The "some" to whom Heidenstein referred may have included the Polish commander Georg Farensbach, who passed on a similar rumor, that Ivan killed his son because the latter wanted to lead the army at Pskov, in May, $1582 .{ }^{47}$ Obviously a variety of contradictory rumors were circulating in the Polish camp, Heidenstein's second version being the exact opposite of the rumor Possevino reported to Galli, where Ivan Ivanovich desired peace, not to lead the war. The Polish camp was hundreds of miles away from the scene of Ivan's death. We have no idea what the sources of the rumors were, but Russian deserters or prisoners were no more likely than the Poles themselves to have accurate information. Jerome Horsey was not in Russia at the crucial moment and wrote his account much later. Giles Fletcher came to Russia in the 1590's, was well educated, and seems to have used Possevino or Heidenstein as a source.

Finally, no contemporary Russian sources say more than that the tsarevich died. There is one brief note from Ivan IV to Nikita Romanovich Iur'ev and Andrei Shchelkalov from Alexandrova Sloboda on 12 November, 1581 reporting that he, the tsar, could not come to Moscow because of his son's illness, but with no more details. ${ }^{48}$ Some later sources report the story that Ivan killed his son, but most of them present the story as a rumor. The Pskov III Chronicle, Arkhivskii spisok, only recorded that "glagoliut netsyi" that Ivan struck his son, but it does not actually say that he killed him, and noted his death without comment. ${ }^{49}$ The Pskov chronicle is sometimes quoted inaccurately as saying Ivan killed his son..$^{50}$ In any case it is a source compiled after the Time of Troubles. The same is true of the 1617 Khronograf and the work of Ivan Timofeev, whose Vremennik also reported that "glagoliut netsyi," Ivan killed his son. ${ }^{51}$ Timofeev did not himself vouch for the rumors, nor did the author of the Khronograf. None of these stories had anything like the apparent reliability of Possevino's version.

Two larger issues arise from the story of Possevino's deception about his knowledge of the death of the tsarevich. One is that the story arose from rumors in the Polish camp, which formed part of the larger history of the intentions of the kings of Poland and other Polish political actors toward Russia, and their understanding of Russian politics in the sixteenth century. B.N. Floria and a variety of Polish historians have identified evolving political program at the Polish court and in the diet toward Russia. Basically, both groups

Cahiers du monde russe, 55/1-2 | 2014 
wanted in some way to put Russia and the Polish-Lithuanian state together, with Russia either as a subject state (the royal agenda) or as some sort of partner (some circles among the szlachta represented in the diet). This platform, though it had some earlier roots, came into being in the course of the 1560's. It was in part a reaction to the Livonian War, that is to Ivan's attempts to incorporate all or part of the Grand Duchy of Lithuania, along with Livonia, into Russia. While the Russians also toyed with peaceful means, such as getting the tsar or his sons elected Grand Duke of Lithuania or King of Poland, Ivan was waging war in the 1560's and the Poles had to respond. The election of Stefan Batory in 1576 brought to the Polish throne an aggressive proponent of war and conquest, which provoked a corresponding reaction in the diet suspicious of possible royal plans for a grab for power through military success in the east. ${ }^{52}$

The relevance to the Possevino story lies in the belief in Poland that Russian politics was filled with conflict, inside the elite and between the tsar and the elite. This is how they seem to have read the events of the Oprichnina. As we know, in general they were not wrong, but they exaggerated the amount of conflict and got many of the details wrong. From a distance it was hard to make out the alliances and conflicts at the Russian court, as the Poles relied on interrogations of prisoners of war, deserters, and the information picked up by Polish diplomats in Moscow on their short and heavily guarded journeys to meet the tsar and his officials. The rumors that Possevino heard and rewrote in the Moscovia, were all about that sort of conflict, in this case within the ruling dynasty in its most important relationship, that of ruler and heir. The Poles got out of these rumors what they wanted to hear, especially the king and his more militant officials, like the Chancellor Jan Zamoyski. Floria's works and the various collections of sources are full of such rumors. They were an important part of the political calculus in Russian-Polish relations. Possevino was not constructing something new and unheard of, such rumors circulated continuously in the court and government of Poland from at least the 1560's until the end of the Time of Troubles. Ivan himself may have contributed to such rumors. 53

The other larger issue may be put simply. Does the truth or falsehood of Possevino's story make any difference? Perhaps it does not make a large difference in itself, but the relations inside the family of a ruling monarch in the pre-modern world should not be left as material for historical novelists. Historians still normally treat monarchies as institutions: they study the formal legal structure, the system of power, more recently client-patron relations among the elite and the composition of that elite, the culture of the court. A monarchy, however, is a family at its core, and how that family lived was an important component of the "state," as we call it.

To conclude: the story told by Possevino in his Moscovia contained a number of statements that were not true. The most obvious is that neither of his interpreters were anywhere near Ivan and his son in the days when the tsarevich was ill and died. This conclusion arises from Possevino's own letter of 16 November 1586 to Ivan, printed as an appendix to the Moscovia itself. The only reason that the readers did not see the deception is that few if any of them in 1586 knew the exact date of the death of the tsarevich. Modern historians do not have that excuse. The second falsehood was that the story was the result of conscientious investigation, conveyed to him by his interpreter. 
His private letter to Galli of 22 January 1582 states that the story was a rumor he heard in the Polish camp near Pskov and that he did not believe it. The third falsehood was that the death of the tsarevich was the result of a quarrel about the wife of the tsarevich and that it inclined Ivan to listen to Possevino's peace proposals. The rumor Possevino heard in late January was that Ivan Ivanovich wanted peace and his father did not. In fact Possevino's actions and correspondence, published at the time and unpublished, demonstrate that he believed Ivan to be inclined toward peace from the time he first encountered the tsar in August, 1581. Possevino's unpublished correspondence with the Vatican, Polish officials, and the Venetian Senate shows that he returned to the subject of the tsarevich several times in the ensuing year 1582 but never mentioned murder or killing, only death. Later correspondence with the Vatican reveals that he wrote the chapter (commentary) containing the story only some time in 1583 , while he was in Hungary, and that he wrote it in response to orders (unspecified).

The story in reality came not from careful investigation discovered by Possevino's interpreters, but from political rumors in the Polish court and army, and are a part of the history of Polish perceptions of Russia and related political schemes. Equally importantly, the story is part of the history of the last years of the Riurikovich dynasty, the clan that had ruled Russia for centuries, and as noted earlier, a monarchy is a family. It matters how the father dealt with his son.

\section{NOTES}

1. Charles Halperin, "Sixteenth-Century Foreign Travel Accounts to Muscovy : A Methodological Excursus," The Sixteenth-Century Journal, 6, 2 (October, 1975) : 89-111; Gabriele Scheidegger, Perverses Abendland- barbarisches Russland: Begegnungen des 15. und 17. Jahrhunderts im Schatten kultureller Missverstandnisse (Zurich: Chronos-Vert, 1993); Marshall Poe, Foreign Descriptions of Muscovy: An Analytic Bibliography of Primary and Secondary Sources (Columbus, OH : Slavica Publishers, 1995); Marshall Poe, A People Born to Slavery: Russia in Early Modern European Ethnography, 1476-1748 (Ithaca, NY : Cornell University Press, 2001).

2. Sigmund von Herberstein, Rerum Moscovitarum commentarii, Vienna, 1549 ; Idem, Moscoviter Wunderbare Historien, Basel, 1563; Russian translation: A.L. Khoroshkevich, ed., Zapiski o Moskovii, 2 vols., M., 2008 ; Giles Fletcher, of the Russe Commonwealth, in Lloyd E. Berry and Robert O.Crummey, eds., Rude and Barbarous Kingdom (Madison: University of Wisconsin, 1968), 87-246; Adam Olearius, Vermehrte Newe Beschreibung der Muscowitischen und Persischen Reyse, ed. Dieter Lohmeyer (Tübingen: Max Niemeyer, 1971). The few surviving Herberstein reports are in Joseph Fiedler, "Aktenstücke zu Siegmunds Freiherrn von Herberstein zweiter Mission nach Russland 1525-26," in Fr. Miklosich, J. Fiedler, eds., Slavische Bibliothek oder Beträge zur slavischen Philologie und Geschichte II (Vienna, 1858), 63-93.

3. On Possevino see Liisi Karttunen, Antonio Possevino, Un diplomate pontifical au XVI ${ }^{\mathrm{e}}$ siècle (Lausanne : Pache-Varidel \& Bron, 1908); Jan Joseph Santich, Missio Moscovitica : The Role of the Jesuits in the Westernization of Russia 1582-1689 (New York : Peter Lang, 1995), 85-111 ; Stéphane Mund, Orbis russiarum : genèse et développement de la représentation du monde "russe" en 
Occident à la Renaissance (Geneva : Librairie Droz, 2003), 217-220 ; and the work of Paul Pierling, La Russie et le Saint-Siège : études diplomatiques, vol. II (P. : Plon, 1897).

4. Paul Bushkovitch, Peter the Great : the Struggle for Power 1671-1725 (Cambridge: Cambridge University Press, 2001) ; Idem, "Aristocratic Faction and the Opposition to Peter the Great," Forschungen zur osteuropäischen Geschichte 50 (1995) : 80-120.

5. N.M. Karamzin, Istoriia gosudarstva Rossiskogo [History of the Russian State](reprint edition, M., 1989 [originally SPb., 1840's]), kn. 3, cols. 208-09 [original vol. 11, chapter 5] ; S.M. Solov'ev, Istoriia Rossii s drevneishikh vremen [History of Russia from Most Ancient Times], 15 vols, (M. : Izd. Sotsial'noi ekonomicheskoi literatury, 1960-1966), vol. 3, 703-704, 739-740 [original vol.6, 1856] ; S.F. Platonov, Ocherki po istorii Smuty v Moskovskom gosudarstve XVI-XVII vv. [Sketches of the History of the Time of Troubles in the Moscow State in the $16-17^{\text {th }}$ Centuries] (3d ed., SPb. : Bashmakova, 1910), 179 ; R.G. Skrynnikov, Ivan Groznyi (M., 1973), 234-236 ; A.A. Zimin, V kanun groznykh potriasenii : predposylki pervoi krest'ianskoi voiny v Rossii [On the Eve of Stormy Disturbances : the Preconditions of the Peasant War in Russia] (M. : Mysl, 1986), 90-93 ; Andrei Pavlov and Maureen Perrie, Ivan the Terrible, (London : Pearson, Longman, 2003), 192-193 ; Isabel de Madariaga, Ivan the Terrible : First Tsar of Russia (New Haven : Yale University Press, 2005, 340-341.

6. On the later impact of the story see among other works Alain Besançon, Le tsarévitch immolé, la symbolique de la loi dans la culture russe (P., 1967), Maureen Perrie, The Image of Ivan the Terrible in Russian Folklore (Cambridge : University Press, 1987) ; idem, The Cult of Ivan the Terrible in Stalin's Russia (Basingstoke : Palgrave, 2001) ; N.N. Mut'ia, Ivan Groznyi : istorizm i lichnost' pravitelia v otechestvennom iskusstve XIX-XX vv. [Ivan the Terrible: Historicism and the Personality of the Ruler in the Art of the Fatherland in the $19-20^{\text {th }}$ Centuries] (SPb. : Aleteiia, 2010).

7. Alexander Filjushkin, Ivan the Terrible : a Military History (London : Frontline Books, 2008), 239-242 ; Zimin, V kanun groznykh potriasenii, 76-78 ; V.V. Novodvorskii [Witołd Nowodworski], Bor'ba za Livoniiu mezhdu Moskvoi i Rech'iu Pospolitoiu (1570-1582) [The Struggle for Livonia between Moscow and Poland (1570-1582], Zapiski istoriko-filologicheskogo fakul'tetat imp. S-Peterburgskogo universitetu 72 (SPb., 1904), 217-228.

8. Novodvorskii, Bor'ba za Livoniiu, 255-303.

9. Antonio Possevino, Moscovia (Wilno, Apud Ioannem Velicensem, 1586) [available on Google books and at Biblioteca Digital Hispanica, Biblioteca Nacional de España] ; also Antwerp, 1587 ; Italian translation as Commentarii della Moscovia (Mantua, 1610 [originally 1592]). English: Hugh F. Graham, ed. and trans., The Moscovia of Antonio Possevino, S.J. (Pittsburgh, 1977); Russian: A. Possevino, Istoricheskie sochineniia o Rossii [Historical Works on Russia], (trans. L.N. Godovikova, M., 1983) ; Polish: Antonio Possevino, Moscovia, (trans., Albert Warkotsch, Warsaw, 1988). The text in A.I. Turgenev, ed., Historiæ Ruthenicæ Scriptores, (Berlin-SPb., 1842), vol. 2, 275-366 reverses the order of the two commentaries. Godovikova, who used this version, also reversed the order of the two commentaries. Graham used the 1587 Antwerp edition which followed the order of the Wilno editio princeps but omitted the appendix of letters in the 1586 and other editions.

10. Graham, The Moscovia of Antonio Possevino, 12-13, 146. Graham did not indicate a source for the information about the interpreters but presumably it was Pierling, who believed that the source was Possevino's other interpreter Vasilii Zamaskii: Paul Pierling, Papes et Tsars (1547-1597) : d'après des documents nouveaux (P. : Retaux-Bray, 1890), 304 ; and Idem,

La Russie et le Saint-Siège, 160-161.

11. Possevino, Moscovia, 1586, 13v-14v ; 1587, 28 ; Historiæ Ruthenicæ II, 292-93. The Italian translation was more definite: "per manifesto inditio" for "certiore indicio" and "vera" for "veriore" : Possevino, Commentarii, 38-39.

12. Possevino, Moscovia, 1586, 13v ; 1587, 28 ; Historiæ Ruthenicæ II, 292-93. 
13. Possevino, Moscovia, 1586, 13v ; 1587, 28 ; Graham, The Moscovia of Antonio Possevino, 12 ; Godovikova, Istoricheskie sochineniia, 50.

14. Pierling, La Russie II, 160. Pierling offered no source for the conclusion, though he clearly read Possevino's letters in the Moscovia and elsewhere.

15. Possevino, Moscovia, 1586, 208-208v ; Idem, Moscovia et alia opera, 1595, 67 ; Godovikova, Istoricheskie sochineniia, 104-105; Zimin, V kanun groznykh potriasenii, 90, 265. The Russian version of Possevino's letter is in F.I. Uspenskii, Peregovory o mire mezhdu Moskvoi i Pol'shei v 1581-1582 gg. [Peace Negotiations between Moscow and Poland sen 1581-1582](Odessa, 1887), 39-40.

16. Pamiatniki diplomaticheskikh snoshenii drevnei Rossii s derzhavami inostrannymi [Monuments of Diplomatic Relations of Ancient Russia with Foreign Powers] SPb., 1851-1871, X, 248-258; Godovikova, Istoricheskie sochineniia, 102-103.

17. Possevino, Moscovia, 1586, 227-227v ; Idem, Moscovia et alia opera, 1595, 72-73 ; Idem, Commentarii, 155 ; Godovikova, Istoricheskie sochineniia, 117, 120. Ivan's letter to King Stefan and his safe-conduct for the Polish negotiators were dated October 27 : M. Koialovich, Dnevnik posledniago pokhoda Stefana Batoriia na Rossiiu (osada Pskova) i Diplomaticheskaia perepiska togo vremeni otnosiashchaiasia glavnym obrazom k zakliucheniiu Zapol'skago mira [A Diary of the Last Campaign of Stefan Batory against Russia (the Siege of Pskov) and the Diplomatic Correspondence of that Time Relatiing Mainly to the Conclusion of the Peace of Zapol'e] (SPb., 1867), 372-373.

18. "Nos emendatiora ab ipso Auctore consecuti," Possevino, Moscovia 1586, "Typographus lectori" unpaginated introduction.

19. Possevino, Moscovia, 1586, 1v. Cf. Graham, The Moscovia of Antonio Possevino, 1 : "during my absence of five months from Muscovy I left two men with the Prince and they were able to make numerous observations." See also Possevino's letter to father Jakub Wujek in Transylvania from the Polish camp at Pskov, Oct. 8, 158, stating that he left Drenocky in Moscow, in Andreas Veress, Epistolæ et acta Jesuitarum Transylvaniæ temporibus principum Bathory (1571-1613), (2 vols. Budapest, 1911-13), (Fontes rerum Transylvanicarum 1 and 2), vol. 1, (Budapest, 1911), 201.

20. Possevino, Istoricheskie sochineniia, 238 ; Possevino, Moscovia, 1586, 18-18v ; Cf. Graham, The Moscovia of Antonio Possevino, 17 ; Pierling, La Russie, II, 161 ; Idem, Méthode Lerpigny, Un arbitrage pontifical au $\mathrm{XVI}^{\mathrm{e}}$ siècle: mission diplomatique de Possevino, 1581-1582 (Bruxelles: Société belge de libraire, 1890), 90-91 ; A.I. Turgenev, ed., Supplementum ad Historica Russiæ Monumenta (SPb., 1848), 393

21. Paul Pierling, ed., Missio Moscovitica, (P. : apud Ernestum Leroux, 1882).

22. The Campana relation used to compile the "Missio" is found with mention of the tsarevichi in A.M. Ammann, ed., "I.P. Campani Relatio de itinere Moscovitico," in Antemurale, VI (1960-61), 1-85, see 32 ; German translation, "Ein russischer Reisebericht aus dem Jahre 1581," A.M. Ammann, ed., Ostkirchliche Studien X, (1969) : 156-193, 283-300, see p. 184.

23. "Possewin... Moskiewskiego ad sidera tollit." "Nie widziałem, prawi, w nim babariem takiej, jako ludzie mówią : kto sprawy jego ze sprawami wojska tego konferuje, daleko tam wiĘtszĄ bojaźń Boga najdzie." “StĄd mu siĘ podoba Kniaź, że, co słowo, to siĘ przeżegna a obrazków około niego pełno,” A.Czuczyński, ed., X. Jan Piotrowski, Dziennik wyprawy Stefana Batorego pod Psków (Krakow, 1894), 186. Also in Koialovich, Dnevnik. Russian translation : Dnevnik pol'skogo posledniago pokhoda Stefana Batoriia na Rossiiu (Osada Pskova), (trans. O.N. Milevskii, Pskov, 1882). Piotrowski later entered the priesthood.

24. "wieści od į̨zyków, thedy tho powiadayĄ, a wiele sie gich zgadzĄ na yedno, chocz chloptswo, ysz syn starszy Iwan Kniazia Wielkiego umarl, y Knias sam z wielki zalosczi zachorzal, a do czerkwi przyslal ialmuzny, aby za dusz̨̨ syna iego Boga proszono," Józef Siemeński, ed., Archiwum Jana Zamoyskiego (Warsaw, 1909, II), 180. 
25. "Huc nova ad haec delata sunt Magni Ducis primogenitum filium Ioannem mortuum esse," Archiwum, II, 199.

26. "Ex captivis et exploratoribus Novogardia intellexi maiorem natu Mosci filium obiisse," Archiwum, II, 220.

27. Monumenta Poloniæ Vaticana [Hereafter MPV], 8 vols. (Krakow, 1913-1948, vol. V), 168. During the pontificate of Gregory XIII (1572-1585) Galli was the principal "minister" of the pope since the cardinal-nephew was young and inexperienced. See Antonio Menniti Ippolito, "Note sulla Segreteria di Stato come ministero particolare del Pontefice Romano" in Gianvittorio Signorotto and Maria Antonietta Visceglia, eds., La corte di Roma tra cinque e seicento : 'Teatro' della politica europea (Rome, 1998), 167-189. (English translation : Ippolito, "The Secretariat of State as the Pope's Special Ministry," in Signorotto and Visceglia, eds., Court and Politics in Papal Rome 1492-1700 (Cambridge, 2002), 140-144.)

28. "E vulgo cedisse 300 Moschovitas, filium Magni Ducis Moschovitarum ibiden occubuisse, vulneratos et captos plurimos," Archiwum, II, 274.

29. MPV V, 194. The letter was first published in Lerpigny, Un arbitrage pontifical au $\mathrm{XVI}^{\mathrm{e}}$ siècle, 245. Pierling frequently cited the work, but not this letter.

30. Jósef Siemeński, ed., Archiwum Jana Zamoyskiego III (Warsaw, 1913), 11.

31. MPV V, 229 ; MPV VI, 32, 102, 596.

32. Supplementum ad Historica Russiae Monumenta (SPb., 1848), 388-404.

33. Paul Pierling, Bathory et Possevino : documents inédits sur les rapports du Saint-Siège avec les Slaves (P. : Leroux, 1887), 168-193.

34. Pierling, Bathory et Possevino, 172.

35. On Possevino's mission to Hungary see his report in Andreas Veress, ed., Antonio Possevino, Transilvania (1584), Fontes rerum Transylvanicarum III (Budapest, 1913) ; and Istvan Keul, Early Modern Religious Communities in East-Central Europe: Ethnic Diversity, Denominational Plurality, and Corporative Politics in the Principality of Transylvania 1526-1691 (Leiden- Boston, 2006), 131-40.

36. C.E. Napiersky, ed., [Antonio Possevino], Livoniæ commentaries Gregorio XIII scriptus (Riga, 1852), 18-19.

37. Godovikova, ed., Istoricheskie sochineniia, 232.

38. Pierling, Missio. vii-viii ; also published in Monumenta Poloniæ Vaticana VII, 77.

39. Graham, The Moscovia of Antonio Possevino, 1, 44 ; Possevino, Moscovia (1586), pages, (1587), $7,86$.

40. MPV VI, 702.

41. Pierling, Russie, II, 249-273.

42. Pierling, Russie, II, 282-324.

43. Pierling, Russie, II, 314. On Annibale di Capua see Jan Władysław Woś, Santa Sede e corona Polacca nella corrispondenzade Annibale di Capua 1586-1591, Trento, 2004.

44. Pierling, Russie, II, 232-234; Archiwum Jana Zamoyskiego IV (Krakow, 1948), 456-457 (Possevino to Zamoyski, Padua, 16 January, 1588). The "long letter" in question is presumably King Stefan's reply of 2 August, 1581 to Ivan's long letter of 29 June 1581. The Polish king returned Ivan's polemics in kind: D.S. Likhachev, Ia.S. Lur'e eds., Poslaniia Ivana Groznogo [Epistles of Ivan the Terrible] (M.-L., 1951), 213-238; and for Bathory's message, A.I. Turgenev, ed., Historica Russiae Monumenta I (SPb., 1841), 323-350 (Latin) and Kniga posol'skaia Metriki Velikogo Kniazhestva Litovskogo, soderzhashchaia v sebe diplomaticheskie snosheniia Litvy v gosudarstvovanie korolia Stefana Batoriia (s 1573 po 1580 god) [An Ambassadorial Book of the Metryka of the Grand Duchy of Lithuania Containing Diplomatic Relations of Lithuania during the Reign of King Stefan Batory] (M., 1845), 177-206 (Ruthenian).

45. O. Halecki, "Possevino's Last Statement on Polish-Russian Relations," Orientalia Christiana Periodica 19 (1953) : 299-300. 
46. Reinhold Heidenstein, De bello Moscovitico (Wilno 1584), 211 ; reprinted in Historiæ Ruthenicæ Scriptores II, 165; Russian translation: Idem, Zapiski o Moskovskoi voine [Commentaries on the Moscow War], trans. I.I. Vinogradov, V.G. Vasilevskii (SPb., 1889), 241-242 ; Idem, Rerum Polonicarum... libri XII (Frankfurt/Main, 1672), 188 ; Polish translation : Rajnold Hejdensztejn, Dzieje Polski od śmierci Zygmunta Augusta do roku 1594, 2 Vols. (SPb., 1857, vol. 2), 91.

47. Zimin, V kanun groznykh potriasenii, 91-92.

48. N.P. Likhachev, "Delo o priezde v Moskvu Antonio Possevino [Document on Antonio Possevino's Trip to Moscow]," Letopis' zaniatii arkheograficheskoi kommissii [Chronicle of the Activity of the Arkheographical Commission], 11 (1903) : 77-78.

49. A.N. Nasonov, ed., Pskovskie letopisi [Chronicles of Pskov] (M., 1955), 263.

50. For example, Solov'ev, Istoriia Rossii s drevneishikh vremen, III [1960], 703.

51. Andrei Popov, ed., Izbornik slavianskikh i russkikh sochinenii i statei, vnesennykh v khronografy russkoi redaktsii [A Collection of Slavic and Russian Works and Articles included in the Russian Redactions of the Chronographs](M., 1869), 183 ; O.A. Derzhavina, ed., Vremennik Ivana Timofeeva [The Diary of Ivan Timofeev], M., 2004, 19.

52. B.N. Floria, Russko-pol'skie otnosheniia i politicheskoe razvitie Vostochnoi Evropy vo vtoroi polovine XVI-nachale XVII v. [Russian-Polish Relations and the Political Development of Eastern Europe in the Second Half of the $16^{\text {th }}$ and Beginning of the $17^{\text {th }}$ Centuries] (M., 1978) ; Arkadiusz Czwołek, Piórem i BuławĄ : działalność polityczna Lwa Sapiehy, kanclerza liteskiego, wojewody wileńskiego [With Pen and Staff : the Political Activity of Lew Sapieha, Chancellor of Lithuania, Governor of Wilno] (Torun, 2012).

53. In his first epistle to Prince Andrey Kurbskii Ivan praised Constantine for killing his son "tsarstviia radi :" Ia.S. Lur'e, Iu.A. Rykov, Perepiska Ivana Groznogo c Andreem Kurbskim [The Correspondence of Ivan the Terrible with Andrei Kurbskii] (L., 1979), 19. The story that Possevino recounted, however, was not one of execution for the sake of the empire.

\section{ABSTRACTS}

The story of the 1581 death of tsarevich Ivan Ivanovich at the hands of his father, Ivan the Terrible, is a fixture of Russian history. Yet the only contemporary source is the Moscovia of Antonio Possevino, SJ.m first published in 1586. The relevant chapter was composed several years later, and is inconsistent with other information in the book. Possevino's then unpublished correspondence with his superiors in Rome reveals that he regarded the story as rumor and did not believe it. There is no reliable evidence that Ivan killed his son, intentionally or accidentally.

L'histoire selon laquelle, en 1581, le tsarevič Ivan Ivanovič a été tué par son père Ivan le Terrible fait partie intégrante de l'histoire russe. Cependant, Moscovia d'Antonio Possevino SJ, qui est la seule source contemporaine, n'a été publiée pour la première fois qu'en 1586. La partie concernant la mort du tsarevič a été rédigée quelques années après la survenue de l'événement et entre en contradiction avec d'autres informations du livre. La correspondance, publiée plus tard, de Possevino avec ses supérieurs à Rome révèle qu'il prit cette histoire pour une rumeur et n'y prêta pas foi. En effet, rien ne prouve de façon irréfutable qu'Ivan ait tué son fils, de quelque manière que ce soit, intentionnelle ou accidentelle. 
AUTHOR

PAUL BUSHKOVITCH

Yale University, paul.bushkovitch@yale.edu 